\title{
Non-aneurysmal non-traumatic subarachnoid hemorrhage: think also in acute promyelocytic leukemia
}

Hemorragia subaracnóidea não-traumática não-aneurismática: pense também em leucemia aguda promielocítica

Wladimir Bocca Vieira de Rezende Pinto, Paulo Victor Sgobbi de Souza, Adrialdo José Santos

A 45-year-old woman presented with sudden severe excruciating headache. Medical history disclosed intermittent fever and weight loss in the past 3 months. No focal neurological deficits were seen. CT scan disclosed diffuse subarachnoid hemorrhage. Cranial CT angiography showed no intracranial aneurysms (Figure). Laboratory evaluation disclosed thrombocytopenia, anemia and abnormalities of white blood cell. Bone marrow biopsy confirmed acute promyelocytic leukemia (APML).

Cerebrovascular disease is a frequent neurological complication in oncological patients, generally secondary to coagulopathies related to the neoplasm or drug-induced bleeding ${ }^{1}$. Brain hemorrhage is most common in acute leukemias, especially in APML, and sometimes represents the presenting syndrome ${ }^{2}$.
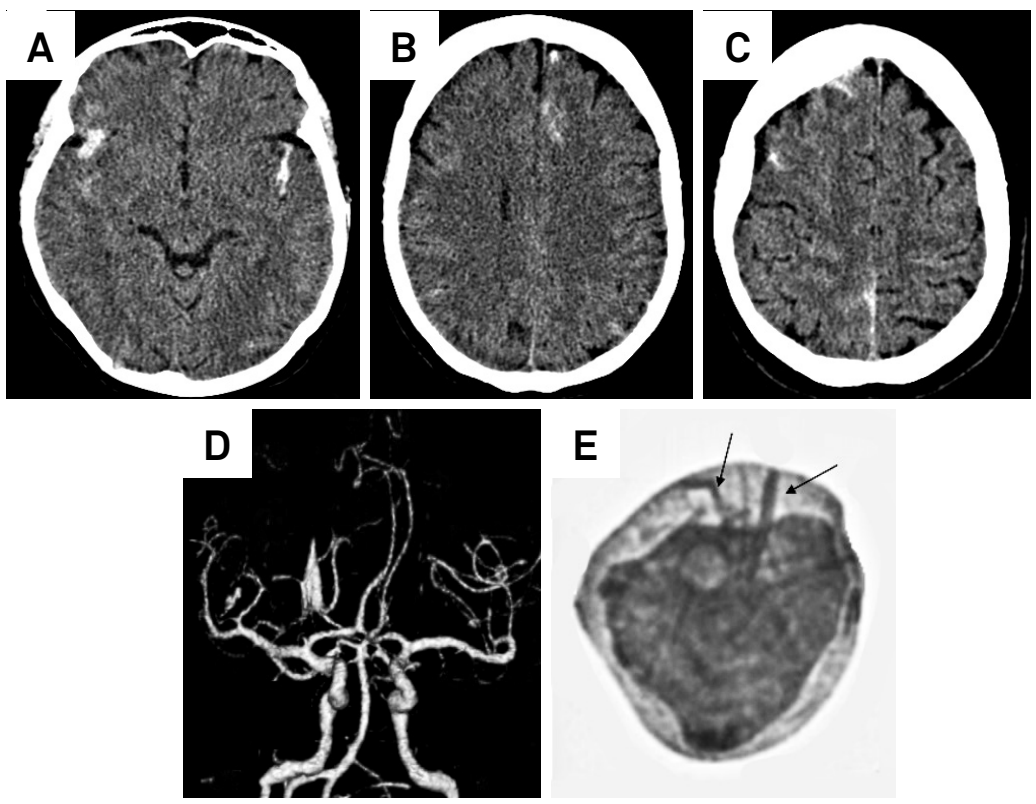

Figure. Subarachnoid hemorrhage in acute promyelocytic leukemia. (A-C) Cranial CT disclosing diffuse subarachnoid hemorrhage. (D) No intracranial aneurysms disclosed by brain CT angiography. (E) Promyelocyte cell with Auer rods (black arrows).

1. Rogers LR. Cerebrovascular complications in patients with cancer. Semin Neurol. 2010;30(3):311-9. doi:10.1055/s-0030-1255224
2. Vásquez E, Lucaya J, Castellote A, Piqueras J, Sainz P, Olivé T, et al. Neuroimaging in pediatric leukemia and lymphoma: differential diagnosis. RadioGraphics 2002;22(6):1411-28. doi:10.1148/rg.226025029 